\title{
A Research for Predictive Value of Hemogram Parameters at Late Term Arteriovenous Fistula Thrombosis Formation
}

\section{Gökmen Akkaya, ๑ Çağatay Bilen}

Ege University Faculty of Medicine, Department of Cardiovascular Surgery, İzmir, Turkey

\begin{abstract}
Objectives: This study aims to assess the relation between late term arteriovenous fistula thrombosis and alteration in hemogram parameters before the occurrence of thrombosis in hemodialysis patients with end-stage renal failure.

Materials and Methods: Data of three hemodialysis centers in our city were evaluated retrospectively. The results of hemogram values before thrombosis formation at first and third month in 14 re-operated patients between March-September 2017, owing to late term fistula thrombosis occurrence, who previously had a successful fistula access, were compared to 73 patients still having hemodailysis therapy via fistula access.
\end{abstract}

Results: Statistically significant increments were measured in neutrophile to lympocyte ratio, red blood cell distribution width, mean platelet volume, platelet distribution width parameters in fistula thrombosis developed patients compared to their previous results three months before thrombosis formation and control group. No significant relation was found between thrombosis formation and other parameters in hemogram.

Conclusion: Herein, it's determined that a profound examination of hemogram has a predictive value for late term fistula thrombosis in hemodialysis patients.

Keywords: Fistula thrombosis, hemogram, neutrophile tolympocyte ratio, red blood cell distribution width, mean platelet volume, platelet distribution width

Address for Correspondence: Gökmen Akkaya, Ege University Faculty of Medicine, Department of Cardiovascular Surgery, İzmir, Turkey Phone: +90 5068610084 e-mail: akkayagokmen@gmail.com ORCID ID: orcid.org/0000-0002-0509-1971 Received: 04.11.2018 Accepted: 11.02.2019

Cite this article as: Akkaya G, Bilen Ç. A Research for Predictive Value of Hemogram Parameters at Late Term Arteriovenous Fistula Thrombosis Formation. EJCM 2019;7(1):9-15.

DOI: $10.32596 /$ ejcm.galenos.2019.00050 


\section{Introduction}

Nowadays, with the advances in healthcare and prolonged life expectancy, there has been an increase in end-stage renal disease patients (ESRDP) ${ }^{(1)}$. In this patient population, autogenous arteriovenous fistula (AVF), which has been created to provide hemodialysis, should be considered as the first choice for vascular access due to its long-term patency, increased patient comfort and low complication rate $^{(2)}$. Complications of vascular access in these patients may cause morbidities therefore patency of an AVF that provides an adequate flow $(300-400 \mathrm{~mL} / \mathrm{min})$ is crucial $^{(3)}$.

Although early stage thrombosis due to AVF is often associated with surgical complications and technique, success for vascular access at one-year postoperatively varies between $42 \%$ and $90 \%$, depending on various reasons ${ }^{(4)}$. As for the cause of thrombosis formation in the late period, neointimal hyperplasia and inflammatory processes are the most common reasons ${ }^{(5)}$. Therefore, many enzymes, hormones and biochemical parameters have been studied so as to identify a predictive marker before the occurrence of thrombosis ${ }^{(5-8)}$.

The hemogram is an inexpensive and fast test that provides extensive information which is frequently utilized in ESRDP. In recent articles, especially, neutrophil to lymphocyte ratio (NLR) and red cell distribution width (RDW) are often associated with inflammatory processes and secondary thrombotic processes ${ }^{(9,10)}$.

In this study, the data of patients who were operated on for late AVF thrombosis and who were receiving routine hemodialysis via AVF were analyzed retrospectively and the relation between AVF stenosis and haemogram parameters was investigated.

\section{Materials and Methods}

For this study, the data of three separate hemodialysis centers in Şırnak province were retrospectively reviewed. Overall 96 patients receiving hemodialysis treatment were evaluated. The case group consisted of 14 patients referred to us from these three centers, whom were afterwards operated on in our institute due to late-onset fistula thrombosis and between March and September 2017. Heretofore, all patients were successfully receiving hemodialysis treatment via AVF.

The patients who had fistula thrombosis in less than a month following AVF opening, or who were still not able to receive a successful hemodialysis treatment with fistula access a month after the AVF opening, were excluded in the study. On the other hand, the control group was comprised of 73 patients who were receiving hemodialysis treatment with AVF access. A total of 87 patients were included in this study. Nonetheless, nine patients undergoing hemodialysis treatment via catheter were not included in any group.

Routine hemogram examines at monthly intervals of these patients at all three centers has being done by the devices of same brand and model (Siemens, Sysmex XT 1800i, Germany).

The device calibrations are supervised by the same biochemistry specialist. Thus, the differences originating from measurement errors among the hemogram values were minimized. Hemogram values were recorded before the thrombosis development at first and third months from the patients who had late fistula thrombosis. In control group, the results of the hemogram which are performed in the last month were evaluated. Case group value at month one recorded as $1 \mathrm{~A}$ and the third month group was $1 \mathrm{~B}$. The control group was named as group 2 and the statistical analysis was performed.

\section{Statistical Analysis}

Statistical Package for Social Sciences Package (SPSS-Chicago, IL, USA) 15.0 programme was used for statistical analysis. The quantitative data was evaluated with chi-square test. Kolmogorov-Smirnov test was used to determine the normal distribution of the variables. Parametrical data analysis was performed by ANOVA instead of Student t-test, as the case group was divided into two subgroups that including the results belonging to $1^{\text {st }}$ and $3^{\text {rd }}$ months. Post-hoc test was utilized to significant $p$ 
values after ANOVA. Paired comparisons were made with Bonferroni Test because of different sample sizes between groups. $\mathrm{P}$ value $<0.05$ was considered as statistically significant.

Informed consent form was obtained from each patient before surgical process.

\section{Results}

A total of 14 fistula patients with AVF thrombosis, had undergone initial AVF opening operations at different dates by various surgeons. Thirteen $(92.8 \%)$ radiocephalic and one $(7.2 \%)$ brachiocephalic anastomosis was performed to those. Nine $(64.2 \%)$ of the radiocephalic fistulas were located at the wrist level (Brescia-Cimino) and 4 (28.5\%) were at the Snuffbox zone. Except for two (14.2\%) Brescia-Cimino fistulas, all Brescia-Ciminofistulas were locating in the left arm. AVF thrombosis occurred in three patients following second AVF opening, and in one, following the third attempt. Previously, all patients were successfully receiving hemodialysis treatment via AVF access. Mean time between AVF opening and thrombosis occurrence was 9 (3-28) months.

Brescia-Cimino fistula was performed in 3 patients in the same forearm with the Snuffbox fistula thrombosis. Among the 9 patients with Brescia-Cimino fistula, three patients underwent thrombectomy, three patients underwent radiocephalic fistula operation at a more proximal level (one of which had developed an early fistula in the 48 hours after thrombectomy). Brachiocephalic AVF was opened to two patients in the same limb and for the other two patients, Brescia-Cimino fistula was created from the other forearm due to multiple and large venous aneurysms. In addition to these, one patient had brachiocephalic AVF from the other arm due to the previous surgical deliveries.

Demographic data such as age, gender and presence of comorbidities were compared with the control group and no significant difference was determined (Table 1).

Hemogram values of the first and third months of the patients before fistula thrombosis occurrence and the patients comprising the control group while receiving hemodialysis via fistula uneventfully were compared. Only four parameters were determined as statistically significant in triple group analysis. Those were RDW $(\mathrm{p}=0.02)$, platelet distribution width (PDW), $(\mathrm{p}=0.04)$; mean platelet volume (MPV), $(\mathrm{p}=0.02)$ and $\mathrm{NLR}(\mathrm{p}=0.01)$ respectively (Table 1). Bonferroni pairwise comparison test was then applied to aforementioned four parameters to distinguish the significant values. When the results of the case group for first month was considered, there was a significantly difference in comparisons with to their third month measurements before thrombosis formation as well as the control group values. However, the third month and the control group values did not differ in paired analysis.

The values were calculated as $\mathrm{p}=0.011, \mathrm{p}=0.016$ for RDW; $\mathrm{p}=0.021, \mathrm{p}=0.034$ for PDW, $\mathrm{p}=0.018, \mathrm{p}=0.026$ for MPV and $\mathrm{p}<0.001, \mathrm{p}<0.001$ for NLR; respectively (Table 2). There was no statistically significant difference between the other paired comparisons.

\section{Discussion}

In this study, four different hemogram parameters were detected that may associate with late term AVF thrombosis. NLR, RDW, PDW, MPV values one month before the thrombosis formation showed an increment when compared with the results of either their values at the third month before thrombosis or control group. Moreover, these outcomes were determined as statistically significant.

There are several studies investigating the physiopathology that underlying AVF thrombosis formation. In the literature, numerous biochemical markers which are frequently used in daily routine have been investigated in order to determine a predictive influence on this issue.

Morton et al. have evaluated 1512 patients from thirteen different studies in their meta-analysis study ${ }^{(11)}$. At the end of the study, no relation was found between AVF thrombosis development and a total of twelve biochemical parameters including hemoglobin levels and C-reactive 
protein (CRP). In contrast to this, Chou et al. designed a study considering the hypothesis that CRP increment is accelerating the neointimal hyperplasia among 51 AVF thrombosis developed patients and determined an association between CRP values and AVF thrombosis formation $^{(12)}$. A similar result was also stated by Kuo et al. ${ }^{(13)}$.

Studies investigating the relationship between AVF thrombosis and the inflammatory process are not limited to CRP. In addition to NLR, RDW is also associated with inflammatory process and assessed in various studies concerning the AVF thrombosis formation. Çiçek et al. have examined the relationship between preoperative NLR and fistula success in a serial of 80 patients from three different centers in their study ${ }^{(14)}$. Consequently, they concluded that an alteration at NLR may be a guide for the treatment and prognosis of AVF thrombosis. Furthermore, Usman et al. determined that NLR and RDW values are associated with the development of fistula thrombosis in their study that consists of 150 patients $^{(15)}$. These outcomes have been corroborated by Bojakowski et al. ${ }^{(16)}$. They conducted a retrospective study aiming to determine the potential risk factors for late term AVF thrombosis and found RDW and NLR values directly related.

Therewithal, similar results for RDW and NLR were found to be significant in terms of early fistula thrombosis. Memetoğlu et al. indicate that RDW and

Table 1. Comparison of demographic data and hemogram values between groups

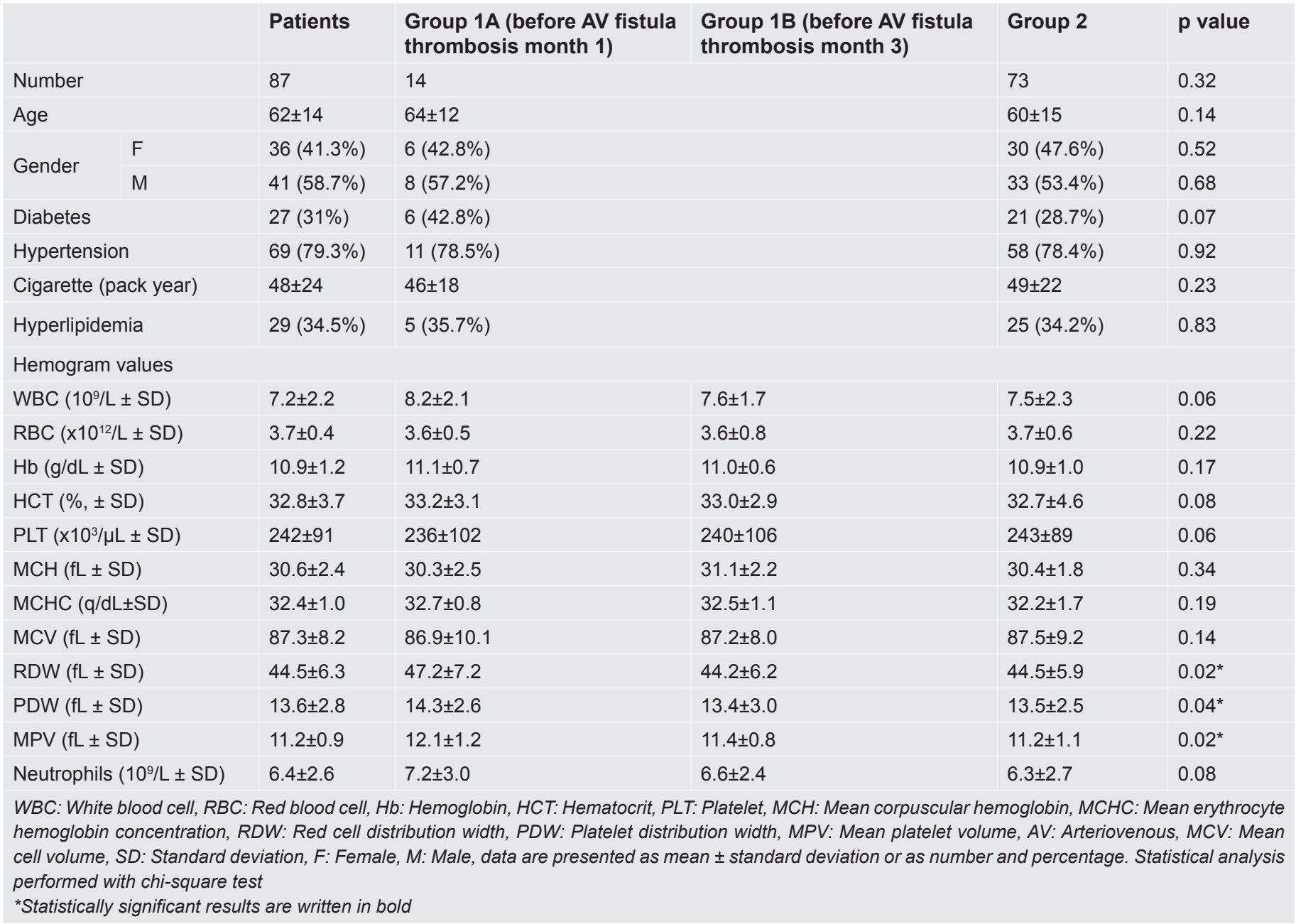


Table 2. Paired comparisons with the bonferroni test of the parameters that calculated significant at ANOVA test

\begin{tabular}{|c|c|c|c|c|c|c|c|}
\hline & & & & & & $95 \%$ se & ity range \\
\hline & & & Averages difference & Standard deviation & p value & Lower limit & Upper limit \\
\hline & Group 1A & $\begin{array}{l}\text { Group 1B } \\
\text { Group } 2\end{array}$ & $\begin{array}{l}3.0 \\
2.8\end{array}$ & $\begin{array}{l}3.004 \\
3.015\end{array}$ & $\begin{array}{l}0.011 \\
0.016\end{array}$ & $\begin{array}{l}0.4 \\
0.5\end{array}$ & $\begin{array}{l}6.1 \\
5.8\end{array}$ \\
\hline RDW & Group 1B & $\begin{array}{l}\text { Group 1A } \\
\text { Group } 2\end{array}$ & $\begin{array}{l}-3.0 \\
-0.3\end{array}$ & $\begin{array}{l}3.004 \\
3.063\end{array}$ & $\begin{array}{l}0.011 \\
0.810\end{array}$ & $\begin{array}{l}-6.1 \\
-3.3\end{array}$ & $\begin{array}{l}-0.4 \\
2.6\end{array}$ \\
\hline & Group 2 & $\begin{array}{l}\text { Group 1A } \\
\text { Group 1B }\end{array}$ & $\begin{array}{l}-2.8 \\
0.3\end{array}$ & $\begin{array}{l}3.015 \\
3.063\end{array}$ & $\begin{array}{l}0.016 \\
0.810\end{array}$ & $\begin{array}{l}-5.8 \\
-2.6\end{array}$ & $\begin{array}{l}-0.5 \\
3.3\end{array}$ \\
\hline & Group 1A & $\begin{array}{l}\text { Group 1B } \\
\text { Group } 2\end{array}$ & $\begin{array}{l}0.7 \\
0.9\end{array}$ & $\begin{array}{l}3.021 \\
3.046\end{array}$ & $\begin{array}{l}0.021 \\
0.034\end{array}$ & $\begin{array}{l}0.4 \\
0.5\end{array}$ & $\begin{array}{l}1.1 \\
1.2\end{array}$ \\
\hline MPV & Group 1B & $\begin{array}{l}\text { Group 1A } \\
\text { Group } 2\end{array}$ & $\begin{array}{l}-0.7 \\
0.2\end{array}$ & $\begin{array}{l}3.021 \\
3.014\end{array}$ & $\begin{array}{l}0.021 \\
0.243\end{array}$ & $\begin{array}{l}-1.1 \\
-0.1\end{array}$ & $\begin{array}{l}-0.4 \\
0.5\end{array}$ \\
\hline & Group 2 & $\begin{array}{l}\text { Group 1A } \\
\text { Group 1B }\end{array}$ & $\begin{array}{l}0.9 \\
-0.2\end{array}$ & $\begin{array}{l}3.046 \\
3.014\end{array}$ & $\begin{array}{l}0.034 \\
0.243\end{array}$ & $\begin{array}{l}-1.2 \\
-0.5\end{array}$ & $\begin{array}{l}-0.5 \\
0.1\end{array}$ \\
\hline & Group 2 & $\begin{array}{l}\text { Group 1A } \\
\text { Group 1B }\end{array}$ & $\begin{array}{l}-0.9 \\
0.1\end{array}$ & $\begin{array}{l}3.042 \\
3.073\end{array}$ & $\begin{array}{l}0.026 \\
0.948\end{array}$ & $\begin{array}{l}-1.3 \\
0.3\end{array}$ & $\begin{array}{l}-0.4 \\
0.5\end{array}$ \\
\hline & Group 1A & $\begin{array}{l}\text { Group 1B } \\
\text { Group } 2\end{array}$ & $\begin{array}{l}0.77 \\
0.70\end{array}$ & $\begin{array}{l}3.002 \\
3.006\end{array}$ & $\begin{array}{l}0.000 \\
0.000\end{array}$ & $\begin{array}{l}0.46 \\
0.35\end{array}$ & $\begin{array}{l}1.08 \\
0.96\end{array}$ \\
\hline NLR & Group 1B & $\begin{array}{l}\text { Group 1A } \\
\text { Group } 2\end{array}$ & $\begin{array}{l}-0.77 \\
-0.07\end{array}$ & $\begin{array}{l}3.002 \\
3.314\end{array}$ & $\begin{array}{l}0.000 \\
0.634\end{array}$ & $\begin{array}{l}-1.08 \\
0.25\end{array}$ & $\begin{array}{l}0.46 \\
0.39\end{array}$ \\
\hline & Group 2 & $\begin{array}{l}\text { Group 1A } \\
\text { Group 1B }\end{array}$ & $\begin{array}{l}-0.70 \\
0.07\end{array}$ & $\begin{array}{l}3.006 \\
3.314\end{array}$ & $\begin{array}{l}0.000 \\
0.634\end{array}$ & $\begin{array}{l}-0.96 \\
-0.39\end{array}$ & $\begin{array}{l}-0.35 \\
-0.25\end{array}$ \\
\hline
\end{tabular}

NLR values are associated with rapidly developing AVF thrombosis and they remark that these parameters may have a cautionary value ${ }^{(17)}$. Despite several hemogram parameters were examined in these studies, the PDW and MPV parameters which are related to platelets were not evaluated. However, we had a change to measure these parameters and the results were found as statistically significant.

Although the increase in MPV and PDW are often associated with thrombotic and inflammatory processes; in literature search, no reports were found considering the patients with the AVF thrombosis. Thus, as per our knowledge, our recent study has to be a feature of being the first study concerning this issue. Besides that, there are several publications on the relationship between these parameters and cardiovascular diseases ${ }^{(18-21)}$. In their meta-analysis study, Chu et al. determined a significant association between MPV increase and acute myocardial infarction and other cardiovascular diseases ${ }^{(20)}$. Therefore, they defined MPV as a prognostic indicator and a risk factor.

There are limited studies investigating PDW. De Luca et al. have determined no significant relationship between coronary artery disease and PDW in a prospective study involving 1882 patients $^{(21)}$. On the other hand, in a study containing 53 patients with cerebral venous sinus thrombosis, Kamışlı et al. found significant increase in MPV and PDW values and therefore suggest that these parameters may be thought as predictive markers ${ }^{(22)}$.

Consistently with the literature in this study, the NLP, MPV, PDW and RDW parameters which are associated 
with inflammatory and prothrombotic processes in prior studies were found to be compatible with late stage AVF thrombosis. The increase between first and third month values before the development of thrombosis was determined as significant. However, no significant difference was evaluated between third month values and control group results in paired comparisons. In the light of these results, we are in opinion that the increase aforementioned parameters may be interpreted in favor of thrombosis development.

Retrospective design, limited patient population and the opening of the initial AVFs by different surgeons constitute the limitations of this study. Further randomized, prospective studies in larger series are needed to support this data.

To summarize, an increase in PDW, MPV, NLP and RDW parameters in a regular and profound hemogram examination has a predictive value and may provide a clinical benefit for AVF thrombosis formation in patients who were receiving hemodialysis via AVF with the diagnosis of end-stage renal failure.

\section{Ethics}

Ethics Committee Approval: Due to the retrospective design of the study, the ethical approval did not obtained.

Informed Consent: Informed consent form was obtained from each patient before surgical process.

Peer-review: Externally peer-reviewed.

\section{Authorship Contributions}

Surgical and Medical Practices: G.A., Ç.B., Concept: G.A., Design: G.A., Ç.B., Data Collection or Processing: G.A., Ç.B., Analysis or Interpretation: Ç.B., Literature Search: Ç.B., Writing: G.A., Ç.B.

Conflict of Interest: No conflict of interest was declared by the authors.

Financial Disclosure: The authors declared that this study received no financial support.

\section{References}

1. Başel H, Çeğin, MB, Aydın, Ü, et al. A Diyaliz amacı ile oluşturulan arteriyovenöz fistül operasyonu sonrası gelișen komplikasyonlar ve buna fistü laçım yerinin etkisi. Van Tıp Dergisi, 2010;17:118-23.

2. Murphy GJ, White SA, Nicholson ML, Vascular access for haemodialysis. Br J Surg 2000;87:1300-15.

3. Konner K, Nonnast-Daniel B, Ritz E, The arteriovenous fistula. J Am SocNephrol 2003;14:1669-80.

4. Allon M, Robbin ML, Increasing arteriovenous fistulas in hemodialysis patients: problems and solutions. Kidney Int 2002;62:1109-24.

5. Roy-Chaudhury P, Khan R, Campos B, et al. Pathogenetic role for early focal macrophage infiltration in a pig model of arteriovenous fistula stenosis. J Vasc Access 2014;15:25-8.

6. Lippi, G, Targher, G, Montagnana, M, et al. Relation between red blood cell distribution width and inflammatory biomarkers in a large cohort of unselected outpatients. Archives of pathology \& laboratory medicine, 2009;133:628-32.

7. Arbel, Y, Finkelstein A, Halkin A, et al. Neutrophil/lymphocyte ratio is related to the severity of coronary artery disease and clinical outcome in patients undergoing angiography. Atherosclerosis, 2012;225:45660 .

8. Marrone D, Pertosa G, Simon M, et al. Local activation of interleukin 6 signaling is associated with arteriovenous fistula stenosis in hemodialysis patients. American Journal of Kidney Diseases, 2007;49:664-73.

9. Taşoğlu İ, Turak O, Nazli Y, et al Preoperative neutrophil-lymphocyte ratio and saphenous vein graft patency after coronary artery bypass grafting. Clinical and Applied Thrombosis/Hemostasis, 2014;20:819-24.

10. Förhécz Z, Gombos T, Borgulya G, et al, Red cell distribution width in heart failure: prediction of clinical events and relationship with markers of ineffective erythropoiesis, in- flammation, renal function, and nutritional state. Am Heart J 2009;158:659-66.

11. Morton SK, Rodríguez AJ, Morris DR, et al. Systematic Review and MetaAnalysis of Circulating Biomarkers Associated with Failure of Arteriovenous Fistulae for Haemodialysis. PLoS One. 2016:26;11 e0159963.

12. Chou CY, Kuo HL, Yung YF, et al, C-reactive protein predicts vascular access thrombosis in hemodialysis patients. Blood purification, $2006 ; 24: 342-6$.

13. Kuo WH, Lee YT, Nang HY, et al, C-reactive protein variability is associated with vascular access outcome in hemodialysis patients. J Clin Lab Anal 2017 Apr 27

14. Çiçek MC, Çiçek ÖF, Özkan T, et al. PreoperatifNötrofil/LenfositOra nınınErkenDönemArterio-VenözFistülBaşarısındakiPrognostikÖnemi. UluslararasıKlinikAraştırmalarDergisi2014;2:31-34.

15. Usman R, Jamil M, Naveed M, High Preoperative Neutrophil-Lymphocyte Ratio (NLR) and Red Blood Cell Distribution Width (RDW) as Independent Predictors of Native Arteriovenous Fistula Failure. Annals of Vascular Diseases, 2016;5:157-60.

16. Bojakowski K, Dzabic M, Kurzejamska E, et al. "A high red blood cell distribution width predicts failure of arteriovenous fistula." PloS one 7.5 (2012): e36482. 
17. Memetoğlu ME, Yilmaz M, Kocaaslan C, et al. Red blood cell distribution width is associated with early failure of arteriovenous fistula for haemodialysis access. Blood Coagulation \& Fibrinolysis, 2015;26:32-35.

18. Gasparyan Y, Ayvazyan L, Mikhailidis D, et al. Mean platelet volume: a link between thrombosis and inflammation?. Current pharmaceutical design, 2011;17:47-58.

19. Sakallı H, Baskın E, Bayrakçı US, et al Mean platelet volume as a potential predictor of renovascular thrombosis after renal transplant. ExpClin Transplant, 2013;11:27-31.
20. Chu SG, Becker RC, Berger PB, et al. Mean platelet volume as a predictor of cardiovascular risk: a systematic review and meta-analysis. J ThrombHaemost. 2010;8:148-56.

21. De Luca G, Venegoni L, Iorio S, et al. Atherosclerosis Study Group. Platelet distribution width and the extent of coronary artery disease: results from a large prospective study. Platelets, 2010;21:508-14.

22. Kamisli O, Kamisli S, Kablan Y, et al. The prognostic value of an increased mean platelet volume and platelet distribution width in the early phase of cerebral venous sinus thrombosis. Clinical and Applied Thrombosis/ Hemostasis, 2013;19:29-32. 